\title{
COMPARING BETWEEN THE AMINO ACID COMPOSITION OF FLAX SEEDS BEFORE AND AFTER GERMINATION
}

\section{Kraievska Svitlana $^{1 *}$, Stetsenko Natalia ${ }^{1}, K$ Korol Oksana ${ }^{2}$}

\author{
${ }^{1}$ National University of Food Technology, Kyiv, Ukraine \\ ${ }^{2}$ Kyiv Cooperative Institute Business and Low, Kyiv, Ukraine
}

Received 21.6. 2017

Revised 26. 6. 2017

Published 27. 11. 2017

\begin{abstract}
Flax (Linum usitatissimum L.) is well known for its health benefits and chemical composition. Flax seeds are emerging as one of the key sources of phytochemicals in the functional food production. In addition, to being one of the richest sources of a-linolenic acid oil and lignans, flax seed is an essential source of high-quality protein and soluble fibre. This study aimed to evaluate the amino acids changes caused by germination. Amino acids are an important component of food. They serve as "building blocks" that make up proteins. Protein deficiency in the body leads to disruption of its normal operation - loss of memory and mental relaxation opportunities and reduce the body's resistance. The effectiveness of the use of protein by the body is determined by two parameters: its balance on the content of essential amino acids and the digestible (dietary) indispensable amino acid score. DIAAS has been adopted internationally as the most suitable method for routine evaluation of protein quality of foods by the Food and Agriculture Organization/World Health Organization. (FAO Food and Nutrition 92, 2013.) We used DIAAS for protein quality evaluation in flax seed and germination flaxseed.
\end{abstract}

Keywords: flaxseed; germination ; amino acids; sprouts; DIAAS

\section{Introduction}

Flax (Linum usitatissimum L.) belonging to family Lineaceae is also known as linseed, which has regained popularity as potential food ingredient because of its nutritional constituents. Nowadays, flaxseed has been recognized as a potential functional food source owing to its bioactive components - omega-3 fatty acid, lignans and dietary fibre (Kajla et al., 2014). The seeds have a crisp, chewy texture and a pleasant, nutty taste. Flaxseed serves as the best and only source of omega-3 fatty acid to the vegetarian diet. Use of natural sources to enhance the nutritional quality of human health is gaining momentum. Germination is a technological application widely used for its ability to reduce the levels of anti-nutritional factors in the seeds and improves the palatability and availability of nutrients (Vidal-Valverde et al., 2002). Most commonly used sprouts to date are from pulses and cereals. Sprout consumption reduced the risk of cancer due to a presence of higher concentrations of health-protecting phytochemicals. DIAAS is the recommended method for dietary protein quality assessment for regulatory purposes, and the use of true ileal digestible amino acid contents in their own right for describing foods is also encouraged.

\footnotetext{
*Corresponding author: Svitlana Kraievska, National University of Food Technology, Kyiv, Ukraine,
} 


\section{Materials and methodology}

It was studied the mature flax "Vruchiy" variety grown in the Kiev region, Ukraine. Flax seeds were cleaned thoroughly to free from dust, dirt and other foreign matter. Damaged seeds were discarded. Flax seeds are difficult to sprout due to a lot of mucilage upon soaking seeds in water. The procedure for obtaining uniformly germinated flax sprouts is described briefly below.

\section{Growing Flax Sprouts}

1. Flax seeds ( $40 \mathrm{~g}$ ) were thoroughly rinsed twice ( $8 \mathrm{am}$ and $4 \mathrm{pm}$ ) with a continuous flow of water using a sieve for one minute on the first day and soaked overnight in Petri dishes.

2. On the second day, the seeds were washed thoroughly to get rid of the mucilaginous gel-like material of the seeds and were uniformly spread on sprouted tray (Tribest. Freshlife. FL-3000, automatic sprouter) and were kept at room temperature. Seeds sprayed 3 times a day with fresh water.

3. On the third day spraying was continued 4 times with fresh water. The sprouted tray with germinating seeds in automatic sprouter "Freshlife FL-3000" was kept at room temperature.

4. On the fourth day, fresh sprouts washed with running water and studied the change in the amino acid composition of flax seeds before and after germination. The quality of the sprout was determined by its uniformity in sprouting, non-sticky tender appearance and fresh spout smell.

\section{Amino acid determination}

The amino acid composition of tested samples was analyzed by ion-exchange chromatography (Llames and Fontaine, 1994). The content of amino acids after hydrolysis with $6 \mathrm{M} \mathrm{HCl}$ was determined using an automatic AA analyzer (AAA T339, Prague, Czech Republic). The amino acid composition was calculated from the areas of standards obtained from the integrator and expressed as percentages of the total protein.

\section{Nutritional quality determinations}

Nutritional qualities were determined on the basis of the amino acid profiles. The Essential Amino Acid Index (EAAl) was calculated using the method of Labuda et al. (1982) according to the equation below:

$$
E A A I=\sqrt[n]{\frac{100 a \cdot 100 b \ldots 100 j}{a v \cdot b v \ldots j v}}
$$

where: $\quad n$-number of essential amino acids; $a, b \ldots j$-the concentration of essential amino acids in a test sample; $a v, b v$...jv - content of the same amino acids in standard protein (FAO/WHO 2013 (older child, adolescent, adult)) respectively

The digestible (dietary) indispensable amino acid score (DIAAS) is the recommended method for dietary protein quality assessment for regulatory purposes (FAO Food and Nutrition 92, 2013.) DIAAS for a food or food ingredient can be obtained from the digestible indispensable amino acid (DIAA) content in $1 \mathrm{~g}$ protein of food and the IAA reference ratio. These values can be calculated using the following equations:

$$
D I A A S=\text { Ileal IAA digestibility * (IAA in protein / IAA requirement })
$$




\section{Results and discussion}

Flax seed proteins are divided into two groups: albumins and globulins (Wanasundara, 1995). Flax is gluten-free. Amino acids are the building blocks of protein. The amino acid pattern of flax protein is similar to that of soybean protein, which is viewed as one of the most nutritious of the plant proteins (Зубцов, 2002). These are the ones that must be included in the diet because the human body cannot make them. Research showed that flax seed protein before and after germination contain 18 amino acids including 10 essential (His + Arg) (Table 1). The amino acid profile of flax showed that Arginine, Leucine, Phenylalanine + Tyrosine was the most abundant, Isoleucine - limited.

Table 1 Amino acid ( $\mathrm{g} / 100 \mathrm{~g}$ of protein) composition of flax seeds and flax sprouts

\begin{tabular}{|c|c|c|}
\hline Amino acids & Flax seeds & Flax sprouts \\
\hline \multicolumn{3}{|c|}{ Non-essential amino acids } \\
\hline Alanine & 5.58 & 6.16 \\
\hline Aspartic acid & 9.09 & 14.01 \\
\hline Serine & 5.83 & 5.79 \\
\hline Glutamic acid & 24.14 & 23.58 \\
\hline Total & 44.64 & 49.54 \\
\hline \multicolumn{3}{|c|}{ Conditionally essential amino acids } \\
\hline Proline & 6.16 & 1.64 \\
\hline Glycine & 7.15 & 6.32 \\
\hline Arginine & 9.57 & 7.26 \\
\hline Cystine & 0.83 & 0.67 \\
\hline Tyrosine & 2.66 & 3.96 \\
\hline Total & 26.37 & 19.85 \\
\hline \multicolumn{3}{|c|}{ Essential amino acid } \\
\hline Lysine & 3.90 & 4.40 \\
\hline Histidine & 1.89 & 1.75 \\
\hline Threonine & 3.66 & 3.93 \\
\hline Methionine & 2.13 & 2.11 \\
\hline Isoleucine & 2.68 & 2.76 \\
\hline Leucine & 6.15 & 6.37 \\
\hline Tryptophan & 0.8 & 0.9 \\
\hline Phenylalanine & 4.31 & 4.06 \\
\hline Valine & 3.48 & 3.72 \\
\hline Total & 29 & 30 \\
\hline
\end{tabular}


Continuation of Table 1

\begin{tabular}{|c|c|c|}
\hline Amino acids & Flax seeds & Flax sprouts \\
\hline \multicolumn{3}{|c|}{ Nutritional quality } \\
\hline TSAA (Meth + cystein) & 2.96 & 2.78 \\
\hline TArAA (Phenyl + Tyro) & 6.97 & 8.02 \\
\hline TEAAs + Arg & 42.06 & 33.86 \\
\hline EAAI & 1.13 & 1.18 \\
\hline
\end{tabular}

TSAAs - total sulfur amino acids, TAAAs - total aromatic amino acids, TEAAs - total essential amino acids, EAAI - the essential amino acid index

The total essential amino acid profile of flax seed and germinated flax sprouts were 29 and $30 \mathrm{~g} / 100 \mathrm{~g}$ respectively. Nutritional quality of flax seeds can be improved by germination process. Germination is extensively helpful in reducing the antinutritional factors to a larger extent (Kajla et al., 2017)

Table 2 Calculation of DIAAS value for flax seed and germinated flax sprouts

\begin{tabular}{|l|c|c|c|c|c|c|c|c|c|}
\hline Parameters & His & Ile & Leu & Lys & SAA & AAA & Thr & Trp & Val \\
\hline $\begin{array}{l}\text { FAO/WHO (older child, } \\
\text { adolescent, adults)* }\end{array}$ & 16 & 30 & 61 & 48 & 23 & 41 & 25 & 6.6 & 40 \\
\hline Flax & 18.9 & 26.8 & 61.5 & 39 & 21.3 & 43.1 & 36.6 & 8 & 34.8 \\
\hline Sprouts & 17.5 & 27.5 & 63.7 & 44 & 21.1 & 40.6 & 39.3 & 9 & 37.2 \\
\hline SID** & 76.4 & 82.3 & 80.6 & 73.9 & 77.6 & 84.7 & 73.5 & 70.5 & 79.8 \\
\hline Digestible IAA ref ratio flax & 90.25 & 73.52 & 81.26 & 60.04 & 71.86 & 89.04 & 107.60 & 85.45 & 69.43 \\
\hline Digestible IAA ref ratio sprouts & 83.56 & 75.44 & 84.17 & 67.74 & 71.19 & 83.87 & 115.54 & 96.14 & 74.21 \\
\hline DIAAS flax & \multicolumn{7}{|c|}{60.04 (Lys) } \\
\hline DIAAS sprouts & \multicolumn{78}{|c|}{67 (Lys) } \\
\hline
\end{tabular}

SAA - sulfur amino acids; AAA - aromatic amino acids; SID - standardized ileal amino acid digestibility;

* amino acid requirements/protein requirements for the selected age groups (FAO/WHO 2013); ${ }^{* *}$ the standardized ileal amino acid digestibility (SID), (Eastwood and Leterme, 2010)

Flax "Vruchiy" contains 24 percent crude protein and also contains appreciable amounts of many of the essential amino acids. The standardized ileal amino acid digestibility (SID) coefficients for the essential amino acids range from 67 to 94 percent, which affects the overall protein quality of the product.

Flax seed proteins are potent multi-functional ingredients for food formulation owing to their techno-functionalities, food preservation capacity, and health benefits. Flax seeds and germinated flax are characterized by a low Lysine content (39.44\% - respectively) in comparison to other meal products and when compared to the requirements of the older child, adolescent, adults (48\%) It will be critical to consider this low Lysine content and digestibility in technologies of functional products. 


\section{Conclusions}

Flax seeds are a source of good fats, quality protein, fiber and minerals. DIAAS for sprouted flax is higher than flax seed by $7 \%$, which characterizes the improvement in the combination of amino acids after sprouting. The use of germinated flaxseeds can be exploited in functional foods, glutenfree technologies, and nutraceuticals industry. Flaxseed and germinated flax are characterized by a low Lysine content (DIAAS 60.04 and 67.74 respectively), it will be critical to consider this low Lysine content and digestibility in technologies of functional products.

\section{References}

Eastwood, L., Leterme, P. 2010. Nutritional value of flaxseed meal for swine and its effects on the fatty acid profile of the carcass. Journal of animal science, vol. 7, p. 3607-3619. DOI: 10.2527/jas.2008-1697.

FAO/WHO, 2013. Dietary protein quality evaluation in human nutrition. Report of an FAO Expert Consultation. FAO Food and nutrition paper, no. 92, 66 p. ISBN 978-92-5-107417-6.

Wanasundra, J.D. 1995. Protein products and sprouts from flaxseed: dissertation these. Department of Biochemistry Memorial University of Newfoundland, Canada. 335p.

Kajla, P., Sharma, A., Sood, D.R. 2014. Flaxseed - a potential functional food source. J Food SciTechnol., vol. 52, p. 1857-1871.

Labuda, J., Kacerovský, O., Kováè, M., Štìrba, A. 1982. Výživa a kŕmenie hospodárských zvierat. Bratislava: Príroda, $164 \mathrm{p}$.

Llames, C.R., Fontaine, J. 1994. Determination of amino acids in feeds: Collaborative study. Journal of AOAC (Association of Official Analytical Chemists) International, vol. 77, no. 5, p. 1362-1402.

Kajla, P., Sharma, A., Sood, D.R. 2017. Effect of germination on proximate principles, minerals and anti nutrients of flaxseeds. Asian J. Dairy \& Food Res, vol. 36, no. 1, p. 52-57.

Vidal-Valverdec, F.J., Sierra, I. 2002. New functional legume foods by germination: Effect on the nutritive value ofbeans, lentils and peas. Eur J Food Res Technol., vol. 215, p. 472-477.

Зубцов, В.А., Осипова, Л.Л., Лебедева, Т.И. 2002. Льняное семья его состав и свойства. Рос. хим. ж. (Ж. Рос. хим. об-ва им. Д. И. Менделеева), т. XLVI, № 2, с. 14-16. 